\author{
Adam Hetmańczuk \\ Wyższa Szkoła Bankowa we Wrocławiu \\ e-mail: adam.hetmanczuk@wsb.wroclaw.pl \\ ORCID: 0000-0001-8843-2577

\section{Tomasz Hetmańczuk} \\ Wyższa Szkoła Bankowa we Wrocławiu \\ e-mail: tomasz.hetmanczuk@wsb.wroclaw.pl \\ ORCID: 0000-0002-6948-9428
}

\title{
CZY ASYMETRIA SALD W SYSTEMIE TARGET2 MOŻE BYĆ INTERPRETOWANA W KATEGORIACH SZEROKO ROZUMIANEJ SHARING ECONOMY?*
}

\section{CAN THE ASYMMETRY OF BALANCES IN THE TARGET2 SYSTEM BE INTERPRETED IN TERMS OF THE BROADLY UNDERSTOOD SHARING ECONOMY?}

DOI: $10.15611 / \mathrm{pn} .2018 .530 .13$

JEL Classification: E21, E42, E58

\begin{abstract}
Streszczenie: Celem artykułu było pokazanie, jak działa w strefie euro system wysokokwotowych płatności dla transakcji transgranicznych. TARGET2 (T2) to jego oficjalny skrót. Po przedstawieniu istoty funkcjonowania T2, w artykule wykazano, że stał się on ukrytym narzędziem Eurosystemu ratowania zagrożonych krajów PIIGS w odpowiedzi na globalny kryzys finansowy z roku 2008 i kryzys zadłużeniowy samego bloku jednowalutowego z roku 2010. Wielu ekonomistów nazywa to stealth bailout. W końcowej części artykułu autorzy stawiają prowokacyjne pytanie, czy można interpretować niepokojącą asymetrię sald w TARGET2 w kategoriach sharing economy. Wniosek końcowy jest zaskakujący: można jeśli zaakceptuje się niekonwencjonalne podejście do sharing economy, w tym na poziomie makroekonomicznym.
\end{abstract}

Słowa kluczowe: Transgraniczny System Płatniczy RTGS, banki centralne, TARGET2, asymetria sald w systemie T2, Eurosystem, ekonomia współdzielenia.

Summary: The purpose of the article is to show how the system of large-volume payments for cross-border transactions works in the euro area. TARGET2 (T2) is its official abbreviation.

* Artykuł został przygotowany w ramach projektów naukowo-badawczych realizowanych w Centrum Badań nad Mikroekonomicznymi Podstawami Makroekonomii, tj. w Zespole Badawczym WSB we Wrocławiu, którym kieruje prof. dr hab. Marian Noga, były członek Rady Polityki Pieniężnej II kadencji (2004-2010). 
After presenting the essence of T2 operations, the article shows it has become a hidden tool of the Eurosystem to rescue the PIIGS-countries in response to the global financial crisis of 2008 and the debt crisis of the single-currency block from 2010. Many economists call this Stealth Bailout. In the final part of the article, the author puts a provocative question on whether the alarming asymmetry of TARGET2 balances in terms of sharing economy can be interpreted. The conclusion is surprising: Yes, it will be possible if an unconventional approach to sharing economy, including at the macroeconomic level, is accepted.

Keywords: RTGS Cross-Border Payment System, central banks, TARGET2, asymmetry of balances in the T2 system, Eurosystem, sharing economy.

\section{Wstęp}

Tytuł artykułu jest zamierzoną prowokacją intelektualną, mającą na celu wywołanie dyskusji. Pojęcie sharing economy, czyli gospodarki współdzielenia, robi zawrotną karierę od czasu wybuchu globalnego kryzysu finansowego dziesięć lat temu. Sama idea sharing economy liczy cztery pełne dekady. W roku 1978 dwaj autorzy M. Felson i J.L. Spaeth użyli po raz pierwszy tego określenia w swoim artykule pt. Community structure and collaborative consumption: A routine activity approach [Felson, Spaeth 1978, s. 614624]. Wtedy nie byli oni w stanie przewidzieć w najśmielszych swoich wyobrażeniach, jak bardzo rozwinie się ich koncepcja w pierwszej i drugiej dekadzie XXI wieku.

W przypadku sharing economy sensu stricto funkcjonują e-platformy, które umożliwiają współużytkowanie lub udostępnianie posiadanych dóbr zarówno przez osoby prywatne, jak i podmioty biznesowe. Na przykład pojęciem sharing economy można objąć również tokeny cyfrowe, czyli tak popularne w ostatnim czasie kryptowaluty, jak bitcoin i wszystkie pozostałe „altkoiny”.

Uciekając się do mocno rozszerzającej interpretacji pierwotnego terminu sharing economy, warto przewrotnie zapytać: czy system TARGET2 można uznać za taką szczególną e-platformę Eurosystemu, która stwarza możliwości „dzielenia się” zasobami pieniądza (płynności) między gospodarkami państw Europy Północnej (w tym głównie Niemiec), a gospodarkami południowych peryferii strefy euro (jak Grecja, Włochy, Hiszpania i Portugalia). Traktować to można w kategoriach dobrze pojętej wspólnotowej solidarności i realnej pomocy wzajemnej krajów tworzących Unię Gospodarczą i Walutową. Od strony czysto ekonomicznej sprawa przybiera jednak wymiar olbrzymich kredytów i wierzytelności liczonych w miliardach euro, co wiąże się niebezpieczeństwem powstania niewypłacalności w przypadku wystąpienia zadłużonego kraju z obszaru jednowalutowego i powrotu do pieniądza narodowego, np. drachmy greckiej, lira włoskiego, pesety hiszpańskiej czy escudo portugalskiego.

Nie bacząc na możliwe konsekwencje finansowe oraz następstwa makroekonomiczne szybko narastającej asymetrii sald w systemie TARGET2, można mimo to podjąć próbę zinterpretowania tego stanu jako niestandardowej realizacji idei sharing economy na poziomie unii monetarnej. Pomysł ten wydaje się dziwny, ale warto go zweryfikować. 


\section{System platniczy TARGET2}

System TARGET2 (T2) jest drugą generacją paneuropejskiego systemu międzybankowych płatności wysokokwotowych (large-value payments) w walucie euro, który funkcjonuje samodzielnie od trzeciej dekady maja 2008 roku. Jego poprzednikiem był TARGET, który działał od roku 1999 przez 3423 dni, do 19 maja 2008 roku. T2 to w pełni zautomatyzowany elektroniczny system rozrachunku brutto (Trans-European Automated Real-Time Gross Settlement Express Transfer System). Umożliwia on błyskawiczne przetwarzanie transakcji pieniężnych w czasie rzeczywistym oraz natychmiastowe zamknięcie rozliczeń. Wszystkie operacje rozrachunku brutto są bezwarunkowe i nieodwołalne. Jest to wyróżnik klasy systemów rozliczeniowych RTGS (Real-Time Gross Settlement). Tej właściwości nie mają systemy bazujące na zasadzie odroczonego rozrachunku netto DNS (Deferred Net Settlement), które dokonują rozliczenia kompensacyjnego na koniec ustalonego wcześniej cyklu rozrachunkowego, np. na koniec dnia operacyjnego lub w jego trakcie. Operatorami systemów RTGS są przeważnie banki centralne, choć zdarzają się wyjątki. Tak jest np. w przypadku systemu CHAPS (Clearing House Automated Payment System) w Wielkiej Brytanii, który obsługuje firma prywatna.

Pierwszoplanowym zadaniem TARGET2 jako jednowalutowego systemu rozrachunkowego w Unii Gospodarczej i Walutowej było radykalne obniżenie ryzyka systemowego oraz zniwelowanie rozróżnienia między transakcjami wewnątrzkrajowymi i transgranicznymi. Tym samym zostały zrównane i ujednolicone opłaty z tytułu realizacji wysokokwotowych zleceń płatniczych w strefie euro, bez względu na to, czy dotyczą one obrotu krajowego, czy ponadgranicznego. Ponadto operacje dokonywane w TARGET2, jak i w poprzednim TARGET, nie są narażone na ryzyko kredytowe, ponieważ kluczową rolę w tym systemie odgrywają banki centralne.

Duże transgraniczne przepływy środków finansowych w formie realizowanych zleceń płatniczych (large cross-border payment flows) są zjawiskiem jak najbardziej normalnym w Unii Gospodarczej i Walutowej 19 państw europejskich, jaką jest strefa euro. Jest to wyznacznik zaawansowania procesów integracji w obszarze rynków pieniężnych bloku jednowalutowego funkcjonującego niemalże od 20 lat. Płynność rozliczeń pieniężnych bez względu na granice państw członkowskich UGiW jest bardzo ważna dla wszystkich uczestników transakcji finansowych w przestrzeni obiegu wspólnego pieniądza. W strefie euro żyje ponad $340 \mathrm{mln}$ ludzi $(340,7 \mathrm{mln}$ w 2017 r.), co stanowi blisko 5\% populacji świata. To więcej niż w Stanach Zjednoczonych (325,7 mln w 2017 r.), które są największą gospodarką na świecie, z PKB wynoszącym w 2017 r. 19387 mld USD (ok. 17167 mld euro).

Rozliczanie transgranicznych płatności odbywa się w pieniądzu banku centralnego strefy euro (EBC), a to oznacza tworzenie sald w systemie TARGET2 dla każdego krajowego banku centralnego wchodzącego w skład Eurosystemu. Generalnie przepływy transgraniczne środków via TARGET2 odzwierciedlają transakcje zainicjowane przez podmioty prywatne, takie jak np. przedsiębiorstwa, instytucje kredytowe czy osoby 
prywatne. Krajowe banki centralne mogą również samodzielnie wywoływać zmiany sald $\mathrm{w}$ systemie, np. w przypadku nabywania aktywów w ramach rozszerzonego programu skupu aktywów EAPP (Expanded Asset Purchase Programme) [The ECB's Expanded Asset...]. Salda w systemie TARGET2 wykazywane przez krajowe banki centralne strefy euro w stosunku do Europejskiego Banku Centralnego są potwierdzeniem na zdecentralizowaną dystrybucję płynności EBC w ramach Eurosystemu. Wynikają właśnie ze swobody transgranicznych przepływów międzybankowych.

System TARGET2 realizuje średnio w ciągu dnia operacyjnego ponad 342 tys. zleceń płatniczych, a przeciętna dzienna skumulowana wartość przeprowadzonych operacji pieniężnych wynosi ok.1,7 bln euro (dane za rok 2016). Jak łatwo obliczyć, statystycznie w ciągu dwóch dni obroty TARGET2 stanowią równowartość produkt krajowego brutto Niemiec (PKB Niemiec w 2017 r. to 3267 mld euro), największej gospodarki strefy euro i czwartej na świecie (po USA, Chinach i Japonii). TARGET2 to największy wysokokwotowy system płatniczy w Europie, gdyż obsługuje 90\% łącznej wartości rozrachunków w euro. Średnia wartość jednej transakcji w T2 to $5 \mathrm{mln}$ euro (2016 r.). Prawie 70\% wszystkich płatności realizowanych za pośrednictwem TARGET2 nie przekracza 50 tys. euro w przeliczeniu na jedno zlecenie przelewu, a tylko $10 \%$ z ogólnej liczny przeprowadzonych transakcji ma wartość powyżej $1 \mathrm{mln}$ euro.

TARGET2 tworzy swoisty pomost między bankami. Za jego pośrednictwem można dotrzeć do 55 tys. banków na całym świecie i wszystkich ich klientów. Niezawodne działanie systemu TARGET2 ma fundamentalne znaczenie dla sprawnego przetwarzania tak gigantycznej liczby płatności transgranicznych oraz dla poczucia komfortu i zadowolenia wszystkich zleceniodawców oraz bezpieczeństwa dokonywanych transakcji.

\section{TARGET2 jako ukryte narzędzie ratowania gospodarek strefy euro}

W okresie poprzedzającym wybuch światowego kryzysu finansowego (GKF) w połowie września 2008 r. krajowe banki centralne (KBC) strefy euro wykazywały w systemie TARGET, a później w TARGET2 zwykle salda niezerowe (dodatnie albo ujemne) w formie należności albo zobowiązań w stosunku do Europejskiego Banku Centralnego. To był stan jak najbardziej normalny, a wysokość indywidualnych sald poszczególnych banków centralnych kształtowała się w przedziale od kilku do kilkudziesięciu mld euro. W relacji do PKB własnego kraju nie przekraczały one 0,9-2,7\% (z wyjątkiem Luksemburga).

Suma wszystkich sald dodatnich (alternatywnie ujemnych) KBC wobec EBC wynosiła do pierwszej połowy 2007 r. blisko 100 mld euro. Na przykład na koniec grudnia 2006 r. suma sald nie przekraczała 85 mld euro. W późniejszym okresie sytuacja zamieniła się diametralnie. Po wybuchu globalnego kryzysu finansowego (15 września 2008 r.) suma sald w systemie TARGET2 na koniec grudnia $2008 \mathrm{r}$. wynosiła już niemalże $400(396,7)$ mld euro i w szybkim tempie dalej wzrastała. Na 
koniec grudnia 2011 r. uległa podwojeniu i przekroczyła 800 mld euro $(817,4)$, a rok później (na koniec grudnia 2012 r.) ,,przebiła” magiczny pułap 1 bln euro (1014,9 mld euro). Z kolei na koniec grudnia 2016 r., po przejściowym spadku w latach 2013-2015, suma sald ponownie przekroczyła 1 bln euro $(1076,1)$. W grudniu 2017 r. była już o ponad $17 \%$ wyższa $(1263,9)$ w porównaniu z grudniem 2012 r., a na koniec marca 2018 r. aż o $23 \%(1323,80)$.

Odnotowany w systemie TARGET2 znaczny wzrost sumy sald krajowych banków centralnych w stosunku do Europejskiego Banku Centralnego w latach 2010-2012 był spowodowany eskalacją kryzysu zadłużeniowego w strefie euro, który „zainaugurował" swoją ostrą fazę w Grecji w maju 2010 r. i ogarnął niebawem pozostałe peryferyjne kraje UGiW położone w Europie Południowej (Portugalię [P], Włochy [I], Grecję [G] i Hiszpanię [S]). Stąd akronim PIGS lub PIIGS (Irlandia [I]) na określenie czterech (pięciu) najsłabszych krajów strefy euro, które najbardziej dotknął kryzys zadłużeniowy w Europie (European Debt Crisis).

Potęgujące się napięcia finansowe w tych krajach w związku z ,interferencją” europejskich skutków globalnego kryzysu finansowego i akceleracją kryzysu zadłużeniowego w samej strefie euro, włącznie z realną groźbą niewypłacalności i bankructwa, były łagodzone przez EBC. Odbywało się to za pomocą „,udostępniania” szerokiego strumienia środków tamtejszym bankom via program skupu obligacji skarbowych (emitowanych przez ich rządy) na rynku wtórnym (SMP/V.2010-IX.2012). Skumulowana wartość programu SMP (Security Markets Programme) na dzień 31 grudnia 2012 r. wyniosła 218,0 mld euro (Włochy: 102,8 mld euro; Hiszpania: 44,3 mld euro; Grecja: 33,9 mld euro; Portugalia: 22,8 mld euro; Irlandia: 14,2 mld euro) [Details on securities holdings...].

Przed wspomnianym kryzysem banki komercyjne tych krajów miały relatywnie łatwy dostęp do środków i funduszy prywatnych. Był to typowy sposób refinansowania się tych instytucji z wykorzystaniem środków obcych. Wtedy poziom awersji do ryzyka potencjalnych zewnętrznych kredytodawców nie odbiegał w sposób istotny od trendu długookresowego, co sygnalizowało kształtowanie się cen zakupu kontraktów na instrumenty pochodne CDS (Credit Default Swap), odzwierciadlających koszt ubezpieczenia od bankructwa (np. Grecja w okresie przed listopadem 2009:1,7-3,0\% dla Five-year Credit-Default-Swap $)^{1}$. Stąd też pozyskiwanie środków w formie transgranicznych pożyczek międzybankowych, inwestycji zagranicznych czy depozytów rodzimych podmiotów było normalną praktyką sektora bankowego. Te źródła pozwalały w miarę skutecznie „rekompensować” odpływy pieniędzy związane z importem netto (towarów i usług) oraz nabywaniem aktywów za granicą.

\footnotetext{
${ }^{1}$ Na przykład w dniu 13.06.2011 r. wzrósł koszt ubezpieczenia od bankructwa Grecji, po obniżeniu długoterminowego ratingu tego kraju do poziomu CCC (extremely speculative) przez Agencję Standard \& Poor's. Notowanie CDS dla Grecji wzrosło o 33 punkty bazowe do 1615 pkt. Po decyzji S\&P należałby zapłacić aż 1615 tys. USD, aby ubezpieczyć na okres 5 lat dług Hellady o wartości $10 \mathrm{mln}$ USD, zawierając kontrakt CDS. Opłata ta stanowi dokładnie 16,15\% wartości długu ubezpieczanego na 60 miesięcy.
} 
W wyniku rozwoju kryzysu zadłużeniowego, szczególnie w grupie krajów PIIGS, i raptownego wzrostu awersji do ryzyka kredytowego związanego z sytuacją gospodarczą oraz stanem finansów publicznych tych krajów, strumień pieniędzy prywatnych przestawał tam napływać. Dostęp do międzybankowego rynku pieniężnego został ograniczony, nowe pożyczki transgraniczne nie były już tak łatwo osiągalne, jak w nieodległej przeszłości, a ponadto szybko rosła fala żądań wierzycieli domagających się spłaty wcześniej zaciągniętych kredytów. Ponadto dochodziło do masowego wycofywania kapitału obcego z sektora prywatnego zagrożonych krajów strefy euro. Wszytko to znalazło odzwierciedlenie we wzrastających zobowiązaniach krajowych banków centralnych państw PIIGS w systemie TARGET2 wobec EBC. Narastaniu sald ujemnych w T2 towarzyszył jednocześnie wzrost należności banków centralnych grupy „rdzenia” strefy euro (np. Niemiec, Holandii, Luksemburga i Finlandii) od EBC. W tych okolicznościach rozwija się w pełnej krasie asymetria sald w systemie TARGET2 w podziale na kraje kumulujące coraz to wyższe roszczenia wobec EBC i kraje wykazujące szybkie zadłużenie się w EBC.

Po globalnym kryzysie finansowym, a zwłaszcza po wybuchu kryzysu zadłużeniowego w samej strefie euro, TARGET2 przekształcił się w nieoficjalny i nieformalny mechanizm wzajemnej pomocy przed bankructwem krajów członkowskich Unii Gospodarczej i Walutowej, oddalając się tym samym od swojej pierwotnej misji jako paneuropejskiego jednowalutowego transgranicznego systemu rozrachunkowego.

System TARGET2 stał się w rzeczywistości zawoalowanym instrumentem ratowania tych gospodarek strefy euro, które były zagrożone upadkiem. Jest wykorzystywany po prostu do prowadzenia zastępczego finansowania, czyli ukrytego bailoutu (stealth bailout), czego nie przewiduje ani statut EBC, ani tym bardziej postanowienia traktatowe o funkcjonowaniu Unii Europejskiej. To sprytny sposób udzielania nieformalnej pomocy finansowej przez Eurosystem, bo w TARGET2 nie ma jakichkolwiek limitów, które mogłyby dotyczyć wysokości sald oraz restrykcji określających terminy ich zredukowania do referencyjnego poziomu, np. trendu długookresowego, wyznaczonego dla szeregów czasowych przed wybuchem światowego kryzysu finansowego. Mechanizm T2 nie dysponuje odpowiednimi zabezpieczeniami dla zaciąganych kredytów czy katalogiem sankcji dla banków centralnych, których zadłużenie w systemie przekroczy określony próg [Turner]. Na przykład Eurosystem nie nakłada jakichkolwiek bezpośrednich restrykcji, jak dużo środków może krajowy bank centralny pożyczać w ramach systemu TARGET2, a sam EBC nie wymaga zabezpieczenia od KBC.

Wniosek z powyższych rozważań nie jest wcale oryginalny. System TARGET2 stanowi „przykrywkę" dla bailoutu peryferyjnych krajów strefy euro „żyjących ponad stan”. Dzięki temu mechanizmowi Eurosystemu państwa z grupy PIGS (PIIGS) nie muszą liberalizować własnych rynków pracy, reformować wewnętrznych spetryfikowanych struktur ekonomicznych ze zbyt wysokimi cenami ani redukować wydatków publicznych, aby w końcu przełamać niekonkurencyjność rodzimych gospodarek m.in. $z$ powodu zbyt wysokich płac, co skutkuje deficytami handlowymi. TARGET2 
Tabela 1. Salda państw strefy euro w systemie TARGET2 w latach 2008-2018

\begin{tabular}{|c|c|c|c|c|c|c|c|c|c|c|c|c|}
\hline \multirow{2}{*}{ Lp. } & \multirow{2}{*}{$\begin{array}{c}\text { Państwo } \\
\text { (data akcesji) }\end{array}$} & \multicolumn{11}{|c|}{ Saldo na koniec grudnia danego roku (mld euro) } \\
\hline & & 2008 & 2009 & 2010 & 2011 & 2012 & 2013 & 2014 & 2015 & 2016 & 2017 & 2018 \\
\hline 1 & $\begin{array}{l}\text { Austria } \\
(1999)\end{array}$ & $-37,2$ & $-23,6$ & $-25,6$ & $-33,8$ & $-37,2$ & $-40,2$ & $-34,1$ & $-32,6$ & $-26,4$ & $-45,9$ & $-47,6$ \\
\hline 2 & Belgia (1999) & $-98,3$ & $-36,7$ & $-12,7$ & $-50,2$ & $-36,4$ & $-10,1$ & $-12,1$ & $-8,9$ & 1,1 & $-36,1$ & $-16,2$ \\
\hline 3 & Cypr (2008) & $-5,8$ & $-5,4$ & $-7,4$ & $-8,7$ & $-8,4$ & $-7,1$ & $-3,0$ & 2,3 & 5,6 & 7,4 & 6,6 \\
\hline 4 & $\begin{array}{l}\text { Niemcy } \\
(1999)\end{array}$ & 96,3 & 164,7 & 306,0 & 497,1 & 703,0 & 542,5 & 475,9 & 597,1 & 742,6 & 906,9 & 923,4 \\
\hline 5 & $\begin{array}{l}\text { Estonia } \\
(2011)\end{array}$ & - & - & - & 0,6 & 0,8 & 1,2 & 0,7 & 1,6 & 1,0 & 0,9 & 0,0 \\
\hline 6 & $\begin{array}{l}\text { Hiszpania } \\
(1999)\end{array}$ & $-27,7$ & $-33,6$ & $-50,8$ & $-150,1$ & $-352,8$ & $-239,9$ & $-191,2$ & $-256,3$ & $-333,4$ & $-373,7$ & $-381,4$ \\
\hline 7 & $\begin{array}{l}\text { Finlandia } \\
(1999)\end{array}$ & 5,3 & 2,3 & 11,9 & 47,1 & 61,0 & 20,4 & 13,8 & 31,8 & 46,1 & 40,4 & 58,9 \\
\hline 8 & Francja (1999) & $-134,3$ & $-73,7$ & $-18,1$ & $-111,9$ & $-79,9$ & $-39,0$ & $-37,8$ & $-55,6$ & $-35,5$ & 30,0 & $-65,8$ \\
\hline 9 & Grecja (2001) & $-29,9$ & $-43,3$ & $-89,3$ & $-105,7$ & $-103,8$ & $-49,4$ & $-44,1$ & $-95,4$ & $-72,2$ & $-59,4$ & $-47,9$ \\
\hline 10 & $\begin{array}{l}\text { Irlandia } \\
(1999)\end{array}$ & $-39,9$ & $-44,1$ & $-144,4$ & $-120,9$ & $-81,5$ & $-52,1$ & $-18,9$ & $-2,6$ & $-1,0$ & 1,9 & 11,1 \\
\hline 11 & Włochy (1999) & 29,6 & 63,5 & 23,0 & $-159,1$ & $-243,4$ & $-220,6$ & $-186,7$ & $-247,4$ & $-363,6$ & $-439,0$ & $-442,5$ \\
\hline 12 & Litwa (2015) & - & - & - & - & - & - & - & 0,9 & $-2,4$ & $-4,0$ & $-5,8$ \\
\hline 13 & $\begin{array}{l}\text { Luksemburg } \\
\text { (1999) }\end{array}$ & 28,4 & 49,2 & 69,3 & 97,7 & 103,5 & 106,7 & 103,6 & 143,1 & 167,0 & 192,1 & 196,8 \\
\hline 14 & Lotwa (2014) & - & - & - & - & - & - & $-2,2$ & $-2,3$ & $-5,2$ & $-6,3$ & $-6,4$ \\
\hline 15 & Malta (2008) & $-0,4$ & $-0,8$ & $-0,9$ & $-0,3$ & $-0,1$ & $-0,1$ & $-1,7$ & $-1,0$ & 1,0 & 4,3 & 3,8 \\
\hline 16 & $\begin{array}{l}\text { Holandia } \\
(1999)\end{array}$ & $-1,6$ & 13,0 & 34,1 & 154,3 & 122,1 & 47,3 & 8,8 & 66,2 & 111,7 & 71,0 & 112,4 \\
\hline 17 & $\begin{array}{l}\text { Portugalia } \\
(1999)\end{array}$ & $-18,0$ & $-23,3$ & $-59,8$ & $-62,6$ & $-66,7$ & $-60,9$ & $-55,0$ & $-60,7$ & $-72,1$ & $-81,2$ & $-82,9$ \\
\hline 18 & $\begin{array}{l}\text { Słowenia } \\
(2007)\end{array}$ & $-3,6$ & $-3,3$ & $-2,7$ & $-2,8$ & $-4,7$ & $-1,6$ & 1,9 & $-0,1$ & $-0,8$ & $-1,4$ & $-0,2$ \\
\hline 19 & $\begin{array}{l}\text { Słowacja } \\
(2009)\end{array}$ & - & $-14,9$ & $-12,8$ & $-11,3$ & 1,8 & 5,6 & 4,2 & 0,6 & $-4,7$ & 9,0 & 10,8 \\
\hline & $\begin{array}{l}\text { Łączna kwota } \\
\text { zobowiązań } \\
\text { wobec EBC }\end{array}$ & $-396,7$ & $-302,7$ & $-424,5$ & $-817,4$ & $-1014,9$ & $-721,0$ & $-586,8$ & $-762,9$ & $-917,3$ & $-1047,0$ & $-1096,7$ \\
\hline & $\begin{array}{l}\text { Łączna kwota } \\
\text { roszczeń } \\
\text { w stosunku } \\
\text { do EBC }\end{array}$ & 159,6 & 292,7 & 444,3 & 796,8 & 992,2 & 723,7 & 608,9 & 843,6 & 1076,1 & 1263,9 & 1323,8 \\
\hline
\end{tabular}

Źródło: opracowanie własne na podstawie danych Europejskiego Banku Centralnego za lata 2008-2018 (do marca 2018 r. włącznie). 
umożliwia finansowanie tych deficytów poprzez pożyczki banku centralnego, a to już jest sytuacja kuriozalna.

Krótką historię kształtowania się sald w systemie TARGET2 w latach 2008-2018 przedstawiono w tab. 1. Zamieszono tylko dane na koniec grudnia każdego roku dla lat 2008-2017 i na koniec marca dla roku 2018.

Jak łatwo zauważyć, nawet z pobieżnej analizy danych z tab. 1 wynika wyraźny podział na dwie podgrupy państw strefy euro ze względu na znak i wysokość sald w T2. Do pierwszej z nich zalicza się kraje wykazujące od lat szybko rosnące roszczenia własnych banków centralnych wobec EBC. Są to Niemcy (od 2008 r.), Luksemburg (od 2008 r.), Holandia (od 2009 r.) i Finlandia (od 2008 r.). Na koniec marca 2018 r. była to kwota 1291,4 mld euro. Należności tylko samych Niemiec wynosiły aż 923,4 mld euro.

Natomiast listę krajów „nieprzerwanie” się zadłużających w EBC za pośrednictwem swoich banków centralnych otwierają Włochy (od 2011 r.), Hiszpania (od 2008 r.), Portugalia (od 2008 r.) oraz Grecja (od 2008 r.). Łączne zobowiązania tych państw wobec EBC osiągnęły na koniec marca 2018 r. wartość 954,7 mld euro. Niezerowe salda w systemie TARGET2 są stanem normalnym w Unii Gospodarczej i Walutowej, ale tak gigantycznych nie można uznać za naturalne. Odzwierciedlają one m.in. nierównomierny rozkład płynności EBC w Eurosystemie. Są w strefie euro kraje, które posiadają jej nadmiar, i są państwa członkowskie posługujące się wspólnym pieniądzem, które odczuwają jej niedobór. Utrzymująca się w strefie euro polaryzacja na gospodarki silne i słabe, a w konsekwencji permanentnie nieprzystające do siebie, generuje w systemie TARGET2 narastającą nierównowagę w formie ujemnych i dodatnich sald rozumianych w kategoriach zobowiązań finansowych wobec Europejskiego Banku Centralnego i należności pieniężnych od niego.

Wysokie i wciąż rosnące salda w systemie TARGET2 mogą być niezwykle groźne, zwłaszcza w przypadku realnych szans odzyskania należności przez wierzycieli. $\mathrm{Na}$ przykład w sytuacji rozpadu strefy euro byłyby bardzo trudne do wyegzekwowania. Niemcy, za pośrednictwem własnego banku centralnego, finansują przedsięwzięcia w krajach peryferyjnych strefy euro. Bank ten spełnia nieformalnie rolę pożyczkodawcy ostatniej instancji (lender of last resort) w stosunku do innego banku centralnego wchodzącego w skład Eurosystemu. Jest to sytuacji kuriozalna, gdyż przyjęło się w dwuszczeblowym narodowym systemie bankowym, że funkcję kredytodawcy ostatniej instancji spełnia bank centralny tylko wobec rodzimych banków komercyjnych, kiedy te nie są w stanie pozyskać środków od innych banków na krajowym rynku międzybankowym. Niemcy, poprzez mechanizm TARGET2, biorą mimowolny udział w konwersji i restrukturyzacji zadłużenia tzw. krajów kryzysowych (crisis countries) strefy euro.

Z fundamentalnych zasad unii monetarnej wynika brak górnych limitów dla sald w TARGET2 jako systemie RTGS, stąd nie ma żadnych formalnych i prawnych ograniczeń w transgranicznych przepływach płatności w ramach jednego bloku walutowego. To, w jaki sposób można próbować rozwiązać ten problem, powinno być tematem kolejnego artykułu. 


\section{Salda systemu TARGET2 w ujęciu sharing economy}

Odnosząc się do tytułu niniejszego opracowania, należy przyjąć, że próba potraktowania występującej asymetrii sald w systemie transgranicznych międzybankowych płatności TARGET2, w szczególny sposób rozumianej konwencji sharing economy sensu largo, jest możliwa do zaakceptowania z czysto naukowego punktu widzenia. Generalnie jest to innowacyjny model, który otwiera szerokie możliwości wykorzystania „mocy” ekonomii współdzielenia w obszarach i dziedzinach dotąd pomijanych lub zupełnie ignorowanych. Wszystko to dzieje się w dobrej wierze, w imię nowych poszukiwań i łamania dotychczasowych schematów myślenia.

To niekonwencjonalne podejście do kumulujących się w T2 zobowiązań i należności krajowych banków centralnych wobec EBC ma rację bytu, jeśli rozpatruje się je właśnie w kontekście „współdzielenia się” płynnością bogatych krajów strefy euro z innymi państwami bloku jednowalutowego, których gospodarki są zagrożone recesją, a ich finanse publiczne są w bardzo złym stanie. Bo jak inaczej, w sposób oryginalny, zinterpretować powstawanie po roku 2014 olbrzymich wierzytelności i długów w Eurosystemie w związku z realizacją rozszerzonego programu skupu aktywów EAPP?

Jest to zapewne wykładnia mocno odbiegająca od ortodoksyjnego rozumienia roli pomocy finansowej w funkcjonowaniu obszaru wspólnego pieniądza, ale rozwiązania o charakterze niekonwencjonalnym stały się swoistą „normą” po wybuchu globalnego kryzysu finansowego. Propagując nowe i niestandardowe miejsce sharing economy $\mathrm{w}$ analizie przepływów pieniężnych między państwami członkowskimi strefy euro z aktywnym udziałem ich banków centralnych, łatwiej zrozumieć naturę transgranicznego ruchu strumieni finansowych w warunkach dużego niezrównoważenia wewnętrznego strefy euro. Jest to kanoniczna wada europejskiej Unii Gospodarczej i Walutowej, wynikająca z niespełnienia przez nią kryteriów optymalnego obszaru walutowego (OCA). Konkluzja tego rozumowania nie musi być zaskoczeniem dla postronnego obserwatora. Na niebezpiecznie powiększające się salda w systemie TARGET2 będącym e-platformą Eurosystemu dopuszczalne jest spojrzenie przez pryzmat koncepcji sharing economy.

Należy mieć nadzieję, że w nieodległej przyszłości idea ekonomii współdzielenia, której kreatywny potencjał jest wprost niezmierzony, będzie przekraczać kolejne restrykcje i granice.

\section{Zakończenie}

Analiza przeprowadzona w artykule nie pozwoliła potwierdzić bezpośrednio tezy o możliwości potraktowania szybko narastającej w ostatnich latach asymetrii sald w systemie TARGET2 jako szczególnego rodzaju działań wpisujących się w kanoniczną postać sharing economy. Niestety, to obiegowe podejście odzwierciedla wyłącznie ,jednowymiarowe" mikroekonomiczne postrzeganie tej interesującej koncepcji i z tego powodu nie ma kreatywnego potencjału na przyszłość. 
Biorąc pod uwagę niezwykle szeroką interpretację tego skądinąd rozwojowego pojęcia (sharing economy sensu largo), można zaryzykować wysunięcie wniosku, że sytuacja panująca w systemie paneuropejskich transgranicznych transakcji pieniężnych w strefie euro przypomina pod względem nieformalnym do złudzenia ideę gospodarki współdzielenia, z tą jednak różnicą, że rozgrywa się w sposób niejawny w ramach unii walutowej. Podmiotami są tu wprawdzie nie indywidualne osoby czy grupy biznesowe, lecz państwa wraz z ich bankami centralnymi. Porzucając zatem ortodoksyjną wykładnię sharing economy, można wykazać, że alarmująca asymetria sald w systemie TARGET2 jest niekonwencjonalnym przykładem ekonomi współdzielenia na poziomie makroekonomicznym. Mechanizm działania jest analogiczny jak w przypadku elementarnych przykładów ekonomii dostępu (access economy). Jedne kraje bloku walutowego „dzielą się” płynnością z drugimi za pośrednictwem TARGET2, co przybiera w systemie formę zobowiązań i należności wobec EBC jako ponadnarodowego banku centralnego ugrupowania integracyjnego ze wspólnym pieniądzem.

Z czystej naukowej ostrożności można zakładać, że być może już w niedalekiej przyszłości idea sharing economy nie tylko będzie powszechnie postrzegana w wąskim wymiarze mikroekonomicznym, ale zostanie również „rozciągnięta” na poziom mezo- i makroekonomiczny, chociaż pierwotnie i genetycznie pozostanie związana z tym pierwszym podejściem.

\section{Literatura}

Co to są CDS-y, czyli jak Grecja wpływa na świat?, http://next.gazeta.pl/Gospodarka /1,125292,11289771,Co_to_sa_CDS_y_czyli_jak_Grecja_wplywa_na_swiat_.html.

Details on securities holdings acquired under the Securities Markets Programme,https://www.ecb.europa.eu/press/pr/date/2013/html/pr130221_1.en.html.

Felson M., Spaeth J.L., 1978, Community structure and collaborative consumption: A routine activity approach, American Behavioral Scientist, no. 21(4), s. 614-624.

Konieczna jest reforma systemu Target2, https://www.obserwatorfinansowy.pl/tematyka/makroekonomia/turner-konieczna-jest-reforma-systemu-target $2 /$

Programm für die Wertpapiermärkte, https:/www.bundesbank.de/Redaktion/DE/Glossareintraege/P/ programm_fuer_die_wertpapiermaerkte.html

Raport Roczny EBC za 2017 rok, http://www.nbp.pl/publikacje/publikacje_ecb/ar2017.pl.pdf

Robimy bilans europejskiego QE, http://www.parkiet.com/artykul/1463845.html\&template=restricted

Security markets programme (SMP), https://www.bundesbank.de/Navigation/EN/Service/Glossary/ Functions/glossary.html?1v2=129548\&lv3=145972

The ECB's Expanded Asset Purchase Programme. Will quantitative easing revive the euro area economy?, http://www.europarl.europa.eu/EPRS/EPRS-Briefing-548976-The-ECBs-EAPP-FINAL. pdf.

Turner P., The ECB must reform Target2 to make it sustainable, https://www.centralbanking.com/central-banks/financial-stability/fmi/3256376/the-ecb-must-reform-target2-to-make-it-sustainable. 